IRSH 49 (2004), Supplement, pp. I97-2 I7 DOI: I0.1017/S002085900400170 I

(C) 2004 Internationaal Instituut voor Sociale Geschiedenis

\title{
Concluding Remarks: Framing Protest in Asia, Africa, and Latin America
}

\author{
Rosanne Rutten and Michiel Baud
}

This volume has presented eight case studies of popular intellectuals on different continents who reflected on society in order to change it. They cover a broad range of people whose activist intellectual work has made a difference: from college-educated environmentalists to autodidact revolutionaries, from indigenous activists to Islamic fundamentalists. We believe there are good reasons to bring together these different historical actors, precisely because there is gain in this diversity: each article highlights specific themes that provide valuable insight in the social dynamics of ideological work. Here, we bring together a selection of these insights and explore, at the same time, how a focus on popular intellectuals allows us to better understand some salient aspects of social contention.

\section{INNOVATORS, MOVEMENT INTELLECTUALS, AND}

\section{ALLIES}

Three types of popular intellectuals (and the fluid boundaries between them) are well represented in this volume: innovators, movement intellectuals, and allies. "Innovators" carve out discursive spaces and "invent" new political discourses for emerging social movements; they may remain loosely connected to a movement but may also become its intellectual leaders. "Movement intellectuals" emerge in the development of social movements and include core activists and leaders. Movement allies include intellectuals who lend their expertise to a specific movement. The roles of these three types may be linked to the trajectories of social movements. ${ }^{\mathrm{I}}$

A typology of popular intellectuals is not an obvious starter for the concluding remarks to a volume that draws attention to the social dynamics of framing. This is even more so when we consider David Smilde's thought-provoking contribution. Smilde argues against a focus on intellectuals (as a category of people) if we want to understand activist

I. Here, we are inspired by Ron Eyerman and Andrew Jamison, Social Movements: A Cognitive Approach (University Park, PA, I99I), which discusses the emergence of different types of activist intellectuals in relation to the different phases of a social movement. 
intellectual activity among ordinary people. Such a focus may overlook, he argues, the informal framing work done by ordinary people who do not share the vocation of intellectuals, and who operate outside of the realm of social movements. He has a good point, and his analysis of informal public discussions is a valuable reminder that popular discourses are also formed and disseminated in fluid networks in public life. Nevertheless, if we want to look more specifically at social movements and those persons within them (or connected to them) who "frame protest", it is worth taking a closer look at the varying relationships they might have to these movements.

"Innovators" are intellectuals who produce new interpretive frames and new languages for articulating collective interests, identities, and claims. Thomas Rochon speaks of "critical communities", i.e. groups and networks of intellectuals who develop new, critical perspectives on particular issues through intensive communication and debate. ${ }^{2}$ The creative, experimental side of their interpretive work is important. They may operate in "cultural niches" such as universities, depend on the media to get their message heard, and may retain a certain autonomy from social movements and other organizations. But their ideas are essential in inspiring social movements, which may adopt their ideas for activist use. For instance, in late-colonial Malaya, liberal journalists and pamphleteers engaged in intense ideological debates on the future of their society with religious leaders, writers, and royal spokesmen. These debates created a new political discourse, which set the ideological terms for subsequent political mobilization and collective action. ${ }^{3}$ Such intellectuals, then, may be particularly important in the initial stages of social movements. Sean Chabot draws an explicit parallel between the African-American intellectuals who were the first to experiment with the Gandhian model, and Rochon's “critical communities".

The persons who define and express a collective identity deserve special mention in this regard. The writers, poets, ritual specialists, historians, and clerics who create an image of a specific community, of people who belong together, may contribute to the creation of an assertive political identity, a definition of a "we-group" that may legitimately claim its collective rights. The poets and singers among the Tuareg who belonged to migrant-worker communities in Northern Africa, are a case in point (Baz Lecocq). In their poems and songs they expressed a militant Tuareg identity, born out of hardship in the diaspora, and spoke of discrimination and liberation in ethnic terms. Like the worker-poets of nineteenth-century France, who imagined the workers as a proud, assertive class, these Tuareg poets crafted

2. Thomas Rochon, Culture Moves: Ideas, Activism, and Changing Values (Princeton, NJ, 1998), pp. 22-25.

3. Anthony Milner, The Invention of Politics in Colonial Malaya: Contesting Nationalism and the Expansion of the Public Sphere (Cambridge [etc.], 1994). 
a political identity that influenced activism and gave direction to the political struggle. Their means of communication were typical of the region: cassettes carried the songs over a wide area, and the emotion-laden messages reached literates and illiterates alike.

Oskar Verkaaik shows how, in Pakistan, Sindhi journalists, teachers, and poets helped define the image of a Sindhi nation. Through poetry in the Sindhi language and history writing with a focus on the region, they framed the region and its people in nationalist terms. There are parallels here, for instance, with poets, composers, and historians in nineteenthcentury eastern Europe who contributed to ethnic-nationalist feelings by providing an emotional and scientific (academic) basis to national images. ${ }^{4}$ In the same vein, indigenous leaders in early twentieth-century Latin America used religious, cultural, and political traditions and images of the past, to create new languages and discourses of contention against a neocolonial state. ${ }^{5}$

The second type of popular intellectuals is directly rooted in social movements. Ron Eyerman introduced the term "movement intellectuals", which refers to "those intellectuals who gain the status and the selfperception of being 'intellectuals' in the context of their participation in political movements rather than through the institutions of the established culture". ${ }^{6}$ These intellectuals have the explicit vocation of promoting and developing a collective action frame in the service of social movements. They consist of framing specialists who play a particularly important role in the more "mature" stages of a movement. Again, this is a mixed lot. On the one hand, they include persons with established credentials as intellectuals, who link up to a social movement or are instrumental in its emergence. Examples are the well-known "vanguards" of revolutionary movements, whose members belong to the educated upper and middle classes, and who derive their political legitimacy from the fact that they are academically and ideologically trained. ${ }^{7}$ On the other hand, they include persons with little formal education or intellectual status, who may be "schooled" into the position of intellectuals within the social movement itself.

Social movements "create spaces for 'ordinary people' to become 'intellectuals', that is, individuals who problematize the routines and

4. Benedict Anderson, Imagined Communities: Reflections on the Origin and Spread of Nationalism (London, 1993, 2nd rev. edn).

5. Silvia Rivera Cusicanqui, "Oprimidos pero no vencidos". Luchas del campesinado aymara y qhechwa de Bolivia, 1900-1980 (La Paz, 1986).

6. Ron Eyerman, Between Culture and Politics: Intellectuals in Modern Society (Cambridge, 1994), p. Is.

7. Michael Walzer, "Intellectuals, Social Classes, and Revolutions", in Theda Skocpol (ed.), Democracy, Revolution, and History (Ithaca, NY, I998), pp. I $27-\mathrm{I} 42$. 
beliefs of everyday life and reflect upon them in a meaningful way". ${ }^{8}$ By providing new means of education and communication (schooling, seminars, and newspapers, for example), social movements can transform ordinary people into intellectuals. They also provide intellectuals with a public by organizing mass meetings and demonstrations. ${ }^{9}$ This process is nicely described by Terry Irving and Sean Scalmer in their analysis of "labour intellectuals" in Australia. ${ }^{10}$ They note that trade unions and political parties provided the institutional means and political space for the emergence of labour intellectuals, with the establishment of a labour press, cultural journals, radio stations, and institutions of working-class education. The "cultural activists" of the indigenous movement in Colombia described by Joanne Rappaport in this volume, are a good example as well. Originating in indigenous villages, they were trained within the indigenous organization, through workshops, movement publications, and other means, and were tasked to "produce a discourse of cultural revitalization" based on ethnographic and linguistic research. They were formed as intellectuals, then, within the organizational and ideological framework of the movement. Although their creative space was delineated by this institutional context, reflection and the articulation of ideas was their main task.

"Movement allies" form our third category. They include intellectuals who put their expertise and networks at the disposal of movements, often when these movements have already developed and received public attention. Pablo Bose's analysis of the Indian anti-dam movement highlights two typical examples. Arundhati Roy exemplifies the category of writers, academics, journalists, and documentary-makers who become engaged "public intellectuals", and express the activist cause in ways that are understandable and acceptable to a wide public. In the process, they link their established audiences of readers and film-viewers to the activist message. "Technical" specialists present a second type. As experts in a certain field of knowledge, specialists in engineering and ecological issues offered their expertise to the anti-dam movement.

The role of these formally-trained specialists as supporters of social movements has become more prominent in the last few decades. On the supply side, one reason is the fast growth of this category as a result of the expansion and specialization of education, in both Western and nonWestern societies. On the demand side, there is a growing need for specialists among social movements. As social movements enter new arenas in which to defend their causes (confrontations with specialized government agencies, international organizations, the modern media),

8. Eyerman, Between Culture and Politics, p. i8.

9. Ibid., p. 84 .

ı. Terry Irving and Sean Scalmer, "Australian Labour Intellectuals: An Introduction”, Labour History, 77 (1999), pp. I-I0, I. 
they need people with the knowledge and skills to perform well in these fields. ${ }^{\text {I }}$ The anti-dam movement of the Narmada Valley offers a vivid illustration. The present-day indigenous movement in Colombia presents another example: university-based anthropologists provide specialist knowledge that legitimizes the claims of the indigenous movement vis-àvis national and international agencies. Since technical and academic specialists have a high status in most societies, their support is all the more valuable for social movements. They may, as Bose has shown, successfully counter the knowledge of the "experts" who are in the service of governments and other influential parties. ${ }^{\mathrm{I2}}$

We should not lose sight, however, of those specialists whose knowledge is not related to the sphere of formal, "modern" education. Shamans are crucial supporters of the Colombian indigenous movement. The movement considers them carriers of the cultural core of the indigenous population, and their "knowledge provides a potent language for the politicized construction of cultural forms" (Rappaport, this volume). Similarly, spirit mediums were important allies of guerrilla fighters in southern Africa. Their support helped to legitimize the guerrilla movement among village populations, and their knowledge and ritual powers offered guerrilla soldiers a sense of security. ${ }^{\mathrm{I} 3}$

The typology provided above masks, of course, the dynamic process of people who become popular intellectuals and take on different roles in the course of their lives. Steven Feierman demonstrates, for example, how Tanzanian peasants transformed themselves into "intellectuals" in the course of the struggle against colonial land policies. ${ }^{14}$ In their analysis of the emergence of a new indigenous movement in Bolivia in the I940s, Jorge Dandler and Juan Torrico show how the difficult situations on the haciendas and the volatile political climate produced new indigenous leaders who, on the basis of their local authority and new political circumstances, developed into popular intellectuals. ${ }^{\text {I5 }}$ Marc Becker, in this volume, gives similar examples for Ecuador. The two Sindhi nationalists who are in focus in Verkaaik's contribution had a chequered career before they became intellectual leaders of a separatist movement; we might say they developed from "innovators" into "movement intellectuals". These

i i. Cf. Eyerman and Jamison, Social Movements, p. Iоo.

I 2. Eyerman and Jamison speak of "counter-experts" in this regard; ibid., p. I०4.

I3. David Lan, Guns and Rain: Guerrillas and Spirit Mediums in Zimbabwe (Berkeley, CA, 1985); Terence O. Ranger, Peasant Consciousness and Guerrilla War in Zimbabwe: A Comparative Study (London, 1985 ).

I4. Steven Feierman, Peasant Intellectuals: Anthropology and History in Tanzania (Madison, WI, 1990).

I s. Jorge Dandler and Juan A. Torrico, "From the National Indigenous Congress to the Ayopaya Rebellion: Bolivia, 1945-1947", in Steve J. Stern (ed.), Resistance, Rebellion, and Consciousness in the Andean Peasant World, 18th to 20th Centuries (Madison, WI, 1987), pp. $34 \mathrm{I}-345$. 
examples demonstrate the crucial importance of a historical, diachronic analysis of the relation between popular intellectuals and social movements. This relationship may change dramatically in the context of changing opportunities and constraints.

\section{ARENAS OF CONTENTION}

Popular intellectuals speak to different audiences at the same time, both internally, within a social movement, and externally, to supporters, opponents, and the media. After all, social movements are the product of the interaction of different social and political groups. Internally, movements are often heterogeneous and constantly run the risk of losing their constituency or falling apart. Externally, they are often forced to make alliances and compromises if they want to be successful. In the process, they run the risk of losing their ideological coherence, or of being incorporated into hegemonic politics and mainstream society. Every social movement faces the challenge of balancing the need to maintain internal solidarity and cohesion while at the same time increasing its external effectiveness and success.

This precarious process requires constant ideological work, in multiple arenas, to articulate demands, forge unity, and legitimize claims. To acquire political leverage, popular intellectuals need to convince their following, or fellow activists. At the same time, they have to convey their ideas to the outside world to justify their demands to powerholders and the public at large. Speaking of Indian nationalism, Partha Chatterjee remarks: "Nationalist texts were addressed both to 'the people' who were said to constitute the nation and to the colonial masters whose claim to rule nationalism questioned." "In the same vein, Charles Tilly observes that those who make claims "must establish themselves in the eyes of others authorities, competitors, enemies, and relevant audiences as voices that require attention and must commonly establish themselves in the face of vigorous opposition". ${ }^{17}$

Rappaport makes several important points in this regard. First, the "internal" process of reaching a certain ideological consensus and developing an interpretive frame may involve different types of intellectuals within the broad network of a movement. Each type may have a different position and function in this network, and different interests. For the Colombian indigenous-rights movement these are, for example, indigenous cultural activists, indigenous politicians, shamans, and urban, left-wing intellectuals (including university professors and anthropolo-

16. Partha Chatterjee, Nationalist Thought and the Colonial World: A Derivative Discourse? (London, I986), p. 30.

17. Charles Tilly, Stories, Identities, and Political Change (Lanham, MD [etc.], 2002), p. 90. 
gists). Second, their various discourses are forged in interaction with their specific audiences, local constituencies, local allies and politicians, national and international supporters, etc. How they interact with external parties also influences their discourses in "internal" debates. Finally, it is in their negotiations and confrontations, among themselves and with external parties, that a single "voice" of the movement is constructed.

"A movement is a field of actors, not a unified entity", William Gamson and David Meyer noted: ${ }^{18}$

The degree to which there are unified and consensual frames within a movement is variable and it is comparatively rare that we can speak sensibly of the movement framing. It is more useful to think of framing as an internal process of contention within movements with different actors taking different positions. ${ }^{19}$

The organizational structure of a movement is also of influence here. In a movement with a decentralized structure, where a central leadership that can dictate a certain interpretive frame is absent, internal debates on the "correct" framing of certain issues may be a permanent characteristic. Quintan Wiktorowicz has shown how Islamic religious scholars function as nodes in a wide network of Islamic fundamentalists, each maintaining his own community of followers. Because Islamic religious authority is fragmented, and the movement has no formal ideological centre, framing contests appear to be a constant feature of the movement.

Movements concerned with identity and gender roles operate in diverse arenas as well. Besides striving for political inclusion, legislative emancipation, and liberation in the private sphere, some Latin American women's movements started to engage, in the late twentieth century, in the struggle against authoritarian regimes, civil war, crime, and neoliberalism. This compelled their leaders and activists to look for diverse alliances (with the state, male-dominated political parties, NGOs), and to use different discourses in the process. Images of motherhood became important markers of the political struggle of women against the Argentine dictatorship (1976-1983) and against poverty and terrorism in Peru. ${ }^{20}$

As local struggles are increasingly linked to international networks of power and support, popular intellectuals need to perform in ever more arenas. Almost all the articles in this collection demonstrate the

I8. William A. Gamson and David S. Meyer, "Framing Political Opportunity", in Doug McAdam et al. (eds), Comparative Perspectives on Social Movements: Political Opportunities, Mobilizing Structures, and Cultural Framings (Cambridge [etc.], I996), pp. 275-290, 283.

19. Ibid.

20. Marguerite Guzmán Bouvard, Revolutionizing Motherhood: The Mothers of the Plaza de Mayo (Wilmington, DL, I994); Diana Miloslavich Tupac (ed.), The Autobiography of Maria Elena Moyano: The Life and Death of a Peruvian Activist (Gainesville, FL, 2000). A sophisticated analysis in terms of "political fields" is offered by Raka Ray, Fields of Protest: Women's Movements in India (Minneapolis, MN [etc.], I999). Ray shows, among others, how activists need to adapt to the specific political cultures that prevail in different political arenas. 
importance of these wider linkages. This is perhaps clearest in the article by Bose, who shows how anti-dam activists in India directed their protests not only to the national state and to regional authorities who were directly responsible for the dam-project, but also to the international institution of the World Bank, which financed the project. By targeting this international institution, they were also able to tap into a wide network of international support. A similar political strategy is apparent in the case of the zapatista rebels in southern Mexico who, after they came out into the open in 1994, have been addressing local, national and international audiences at the same time. It is here, also, that the national and international media function as important intermediaries between local struggles and international audiences. A diversity of audiences and a widening horizon may provide social movements with new constituencies and recognition. But, as is clear from some articles presented here, this also implies new risks for movement leaders and intellectuals. Since they simultaneously operate on different playing fields, their legitimacy as interlocutors and intermediaries may be questioned.

Besides these strategic arenas of struggle, there are also more informal spheres in which the messages of popular intellectuals are heard, debated, and further disseminated. These include the "popular publics" which Smilde introduced in his contribution. Through the fluid networks that take shape in (informal) public debates, new discourses are developed and new publics created.

\section{INTELLECTUALS AND “MASTER FRAMES” IN A GLOBAL W ORLD}

Like all persons engaged in framing, the popular intellectuals discussed in this volume have drawn "on the cultural stock" of the wider society in which they were embedded, for "images of what is an injustice, for what is a violation of what ought to be". ${ }^{21}$ Which "images" were available to them, depended on their position in society, and the ideologies that were known and disseminated within the networks in which they operated. They were active in shaping discourse out of a variety of ideological streams, both locally and globally. Moreover, they were themselves active in crafting social networks that connected them to new sources of ideas. For instance, literate, Spanish-speaking Indian peasants in Ecuador gained access to socialist ideas by linking up with the city-based Socialist - later Communist - Party (Becker); and African-American intellectuals made visits to India to seek contact with specialists in Gandhian thought (Chabot). 
The case studies presented in this collection cover at least four main conceptual fields that have inspired social activism in twentieth-century non-Western societies: Marxism, religious beliefs, notions of "rights" (including indigenous rights), and ideologies of citizenship. These form, in a sense, "master frames", broad interpretative frames that may inspire people and movements as they develop their own specific interpretation of society. These frames "provide a grammar that punctuates and syntactically connects patterns or happenings in the world"; and they function as "master algorithms that color and constrain the orientations and activities" of other movements than those that produced them. ${ }^{22}$ As the contributions to this volume show, such master frames are seldom adopted in toto, but rather function as sources of inspiration and intellectual guidance. They are often applied in quite eclectic (and local) ways.

Marxist ideas have been widely distributed in Asia, Africa, and Latin America since the late nineteenth century. Instrumental in their early dissemination were local intelligentsia with international links, and students (some of whom had studied at universities in Europe or the Soviet Union). Marxism inspired labour unions, peasant movements (mostly under the leadership of urban intellectuals), revolutionary movements, and independence struggles, and parts of the ideology were adopted into official state discourse by the socialist regimes of newly independent states. All these organizations and state institutions contributed, in turn, to a further spread of Marxist ideas, albeit in adapted form to resonate with local cultures and suit local purposes. A popularizing book like Marta Harnecker's Los conceptos elementales del materialismo histórico, published in 1976 by the then most important Latin American publishing house, Siglo XXI, and endlessly reprinted, has been sold in hundreds of thousands of copies in Latin America and can still be found in many provincial bookstores all over the continent. It has influenced the thinking of millions of students, militants, and (other) intellectuals and may serve as a symbol of the importance of Marxist thinking in local settings. ${ }^{23}$

In his article on Ecuador, Becker shows how Marxism functioned as a master frame for local peasant leaders and urban intellectuals in Ecuador, its ideas transmitted through the written media and social movement networks. In the same vein, Marxism has been crucial in the history of social struggle in Africa and Asia. ${ }^{24}$ The Tuareg migrant workers discussed by Lecocq were

22. David A. Snow and Robert D. Benford, "Master Frames and Cycles of Protest", in Aldon D. Morris and Carol McClurg Mueller (eds), Frontiers in Social Movement Theory (New Haven, CT, I992), pp. I33-155, I38, I5 I.

23. Jorge G. Castañeda, Utopia Unarmed: The Latin American Left after the Cold War (New York, 1993).

24. See, e.g. Donald L. Donham, Marxist Modern: An Ethnographic History of the Ethiopian Revolution (Berkeley, CA [etc.], 1999); H. Carrère d'Encausse and S. Schram, Marxism and Asia (London, 1969). 
influenced by the revolutionary discourse disseminated by the "Arab socialist" state media in Libya and Algeria. Marxist journalists and writers in Bombay inspired the Sindhi intellectuals discussed in Verkaaik's contribution who, in turn, reworked these ideas into an eclectic religiousMarxist nationalist frame. A modern adaptation of Marxist ideas can be found in the international critical discourse on "development", and the Indian environmental activists highlighted by Bose made strategic use of this frame.

Religion has provided another, influential framework for articulating claims and suggesting activist solutions. A vast network of religious institutions, schools, places of worship, and media channels, supported by religious intellectuals such as clerics and religious teachers, (re)produce and disseminate ideas that may promote political action. ${ }^{25}$ Such networks may reach across continents. The essays by Verkaaik and Wiktorowicz illustrate the role of Islam in inspiring and legitimizing social movements. Catholicism (in particular Liberation Theology) has played a similar role in Latin America, where it inspired a great variety of social movements. Religious texts like the Koran and the Bible certainly offer arguments for critical interpretations of society; they have been extensively used to address social and political issues and to articulate, and justify, "injustice frames". Internal debates on the meaning of religious texts (and its implication for strategy and action) were apparent in the Islamic movements discussed in this volume. They point to the relevance of divergent interpretations within religious communities for the social and political engagement of clerics. A similar process occurred within the Catholic Church and its related organizations, when in the I 970 s and I 980 s the development of Liberation Theology led to vehement intra-Church struggles. Religious beliefs and symbols may also be adopted into otherwise "secular" movements. ${ }^{26}$ For many movement intellectuals who grew up in religious communities, religion offers a familiar framework and cultural reservoir from which to draw ideas and symbolic resources that are emotive, and that may be part of the "common-sense" beliefs of their constituency.

A third conceptual field that has inspired popular intellectuals concerns rights (including indigenous rights and women's rights), identity, and local interests. Local intellectuals and indigenous cultural leaders traditionally functioned as brokers between the state and local populations, and as such they might even support hegemonic state politics. But under specific historical circumstances they became transmitters of assertive local or

25. See, for instance, Mayer N. Zald and John D. McCarthy, "Religious Groups as Crucibles of Social Movements", in idem (eds), Social Movements in an Organizational Society: Collected Essays (New Brunswick, NJ, I987), p. 67-97.

26. Ron Aminzade and Elizabeth J. Perry, "The Sacred, Religious, and Secular in Contentious Politics: Blurring Boundaries", in Ronald R. Aminzade et al. (eds), Silence and Voice in the Study of Contentious Politics (Cambridge [etc.], 200I), pp. I55-178. 
indigenous sentiments, and articulated counter-hegemonic discourses by making use of local knowledge, indigenous cultural expertise, and specific interpretations of the past.

Rappaport shows how the indigenous movement in Colombia involves a wide variety of indigenous intellectuals, ranging from cultural activists at the core of the movement, to indigenous politicians who frame the issue of indigenous rights in terms of political compromise. In the last few decades, the development of a global network of indigenous activists, whose claims are certified by the United Nations and other official institutions, has fostered a global discourse on indigenous rights, which many local activists have tapped into. ${ }^{27}$ The same can be said of the women's movement, which has increasingly linked networks of women activists all over the world, leading to a global field of discourse. In this way, the language of women's rights and emancipation has become one of the most powerful master frames of the contemporary world. ${ }^{28}$

The three types of frames discussed above have gradually been interwoven with a discourse of nationhood and citizenship, which became internationally accepted and institutionalized from the late nineteenth century onwards. All popular intellectuals discussed in this volume worked, in one way or another, within this "master frame" in order to advance their claims. Exclusion of specific groups remained a prominent feature of the forging of nations in Africa, Asia and Latin America, where lower castes, the "natives" or the "uncivilized" were deemed "unfit" for the exercise of full rights in the modern political community. Gyanenda Pandey and Peter Geschiere write: "the rhetoric of the inclusive claims of liberty and equality that nationalism promote, is accompanied by the practice of excluding numerous classes and communities of precisely those claims". ${ }^{29}$ At the same time, ideologies of equality and modernity pervaded the political rhetoric of modern states and their bureaucracies.

Popular classes and their intellectuals tried to take advantage of these newly articulated state ideologies in which social exclusion was no longer sanctioned by law. This has been clearest in the indigenous movements, where the struggle for equal rights principally aimed at real political and social inclusion in the nation. Hence, Ecuadorian Indian activists began to appeal, in the I920s, to their rights as Ecuadorians (Becker), and

27. Adam Kuper, "The Return of the Native", Current Anthropology, 44 (2003), pp. 389-395; Dorothy L. Hodgson, "Introduction: Comparative Perspectives on the Indigenous Rights Movement in Africa and the Americas", American Anthropologist, I04 (2002), pp. I037-I049. 28. See, for instance, Sonia E. Alvarez, "Latin American Feminisms 'Go Global': Trends of the r 990 s and Challenges for the New Millenium”, in Sonia E. Alvarez, Evelina Dagnino, and Arturo Escobar (eds), Cultures of Politics/Politics of Culture: Re-visioning Latin American Social Movements (Boulder, CO, 1988); pp. 293-324.

29. Gyanenda Pandey and Peter Geschiere (eds), The Forging of Nationhood (New Delhi, 2003), p. II. 
Colombian indigenous activists appealed in the r 990 s to the "minority rights" of an indigenous population within a nation-state (Rappaport). The language of "citizenship" and "rights" also facilitated negotiation with the state, as it was a language that state authorities understood (though not necessarily acknowledged in reality). It created, in this sense, an "arena" for negotiations between contentious groups and the state. ${ }^{\circ}$ Even in dictatorships such as those of Argentina in the period 1976-1983 and present-day Burma, where human rights are systematically violated in daily life, the rhetoric of the opposition remains cast in terms of equality, citizenship, and human rights. Only where a modern state is largely absent or has lost its credibility, as in Rwanda in I994, or where claims for an independent state directly threaten the idea of the nation, as in Biafra or New Guinea, the idea of citizenship loses its significance.

The global exchange of ideas, which intensified in the course of the twentieth century, is increasingly apparent in popular struggles in nonWestern societies. Indeed, this interaction has become so intense that it is sometimes quite difficult to trace the origin of certain ideas. Local users may also "indigenize" imported ideas and give these new meanings. Peter Geschiere has shown, for instance, how the concept of "development", which was introduced in Africa by outsiders, became a widely accepted term in the region; so much so that it can today be considered an indigenous idea in the African countryside. ${ }^{3 \mathrm{I}}$ The same applies to terms like "democracy" and "human rights", which have become part of popular discourse in many regions in the world.

It is, by now, generally acknowledged that the globalization of ideas does not imply a homogenization of contentious action. On the contrary, as the essays presented here make clear, popular intellectuals tend to borrow eclectically from a variety of ideological sources, in order to create frames that apply to local situations and have the potential to support local struggles. In the process, they may change meanings and objectives radically.

Neither should we perceive the global dissemination of ideas as the spread of Western ideas over the world, but as a global exchange resulting in a variety of clusters and arenas of discursive exchange and debate. The essays by Verkaaik and Wiktorowicz give insight into the worldwide discussion within Islamic networks on the interpretation of the Islamic faith and its political and social consequences. Chabot's article presents an example of international intellectual contact that reverses common notions of an all-embracing, Western ideological influence, by showing how Gandhian ideas about nonviolent action gave direction to the civil-rights struggle of African Americans in the United States.

30. See, for instance, Charles Tilly (ed.), Citizenship, Identity and Social History, International Review of Social History, Supplement 3 (Cambridge [etc.], I996).

3I. P.L. Geschiere, Moderne mythen. Cultuur en ontwikkeling in Afrika, inaugural lecture, Rijksuniversiteit Leiden, I989. 
The global flow of ideas is, then, mediated by a variety of actors who select, ignore, dismiss, appropriate, and rework ideas for further dissemination, along specific channels of communication. Chabot's case is particularly insightful here, because it concerns a case of transcontinental diffusion that almost did not materialize: it was not self-evident that the Gandhian repertoire would be adopted by the African-American civil rights movement. Obstacles were produced by activists on the receivers' end, who initially considered the Gandhian action repertoire unfit for local use. Removing these obstacles was, in part, the work of "itinerant" activist intellectuals who, through personal interactions and creative reframing, bridged the cultural divide between the two continents.

A further role of popular intellectuals in this regard is their contribution to the development of "modular" frames and repertoires. Since the nineteenth century, at least, certain activist frames and forms of action have developed into standard models, which are readily transferable to other countries, issues, and populations. The Marxist and nationalist frames are among the best examples of such standard ideological packages. $^{32}$ Strikes, demonstrations, and the writing of petitions are examples of modular forms of collective action. ${ }^{33}$ As Tilly argues, repertoires of collective action are not merely the result of local history; there is also much translocal mimicry and exchange taking place, with activists adapting borrowed forms, in turn, to local conditions. ${ }^{34}$ Popular intellectuals may be the prime actors in such reflexive interactions. They may select elements of discourses for local adaptation, convince their peers and wider audiences that these are worthy of consideration, and strategically position themselves within relevant networks of communication. African-American intellectuals helped to make the Gandhian repertoire of nonviolent action "modular", as mentioned above. Popular intellectuals also play a role in the development of "Black Atlantic" networks through which African-American (political) culture and repertoires are increasingly disseminated on a world scale.

\section{CULTURAL AND SOCIAL BROKERS}

When we consider the networks of communication that channel "flows of meaning" between local, national, and global fields, it is clear that popular intellectuals often function as crucial nodes. They may connect different

\footnotetext{
32. Anderson, Imagined Communities.

33. Sidney Tarrow, Power in Movement: Social Movements and Contentious Politics, 2nd edn (Cambridge [etc.], 1998), pp. 29-42; Mark Traugott (ed.), Repertoires and Cycles of Collective Action (Durham [etc.], 1995); Lex Heerma van Voss (ed.), Petitions in Social History, International Review of Social History, Supplement 9 (Cambridge [etc.], 200I).

34. Charles Tilly, Social Movements, I768-2004 (Boulder, CO [etc.], 2004), pp. I4, 90.
} 
sets of ideas, develop these into new models, and disseminate these along further activist networks. Such cultural brokerage and syncretism are important in the development of activist frames. For instance, when Philippine newspaper editor and activist journalist, Isabelo de los Reyes returned from Spain in I90I, after having spent a year in Barcelona's Montjuich prison in the company of Spanish anarchists, he introduced anarchist and socialist ideas within a network of printers, bookbinders, and lithographers in Manila, who sought his assistance in organizing a self-help association. Working out local forms and improvizing along the way, he became instrumental in forming the first Philippine labour union, which he headed. ${ }^{35}$ This brokerage might lead to unexpected strategies. In Colombia, labour leaders in the coffee sector used strikes as a means for labourers to claim land titles (and ultimately to resume their peasant existence), rather than improve industrial labour relations. ${ }^{36}$ In Africa, local leaders incorporated "traditional" discourses and cultural institutions, like witchcraft and dancing, into anticolonial discourses. ${ }^{37}$

A focus on the persons who make these connections may also show that they are not just cultural brokers, but social brokers as well. ${ }^{38}$ Because they link discourses, they can more easily connect the people who use these discourses. As Bose noted about the activists involved in the anti-dam movement in India, they "act as interpreters and mediators, communicators and translators, they enable dialogue between disparate groups, across communities and across differences". Similarly, as popular intellectuals adapt master frames to local situations, they may also enable a linkage between, say, peasant populations and Communist Party cadres, or between villagers and religious-nationalist activists. ${ }^{39}$ Popular intellec-

35. William Henry Scott, The Unión Obrera Democrática: First Filipino Labor Union (Quezon City, Metro Manila, I992). See for a Latin American example: A. Zulema Lehm and C. Silvia Rivera, Los artesanos libertarios y la ética del trabajo (La Paz, I988).

36. Charles Bergquist, Labor in Latin America: Comparative Essays on Chile, Argentina, Venezuela, and Colombia (Stanford, CA, 1986), pp. 336-354.

37. Terence O. Ranger, Dance and Society in Eastern Africa, I890-I970 (Berkeley, CA, I975); Peter Geschiere, The Modernity of Witchcraft: Politics and the Occult in Postcolonial Africa (Charlottesville, VA, 1997); Jean Comaroff and John Comaroff (eds), Modernity and its Malcontents: Ritual and Power in Postcolonial Africa (Chicago, IL, 1993).

38. Social brokers link previously unconnected persons or clusters of persons (networks) and mediate their relations with one another; Doug McAdam, Sidney Tarrow, and Charles Tilly, Dynamics of Contention (Cambridge [etc.], 200I), p. 26. Cultural brokers provide a link between different systems of meaning, and make these mutually accessible. This definition overlaps with that of "intellectual brokerage," which refers to "the linking of two or more previously unconnected ideas, thinkers, or bodies of thought"; Tilly, Stories, Identities, and Political Change, p. 156 .

39. See, for example, Rosanne Rutten, "Popular Support for the Revolutionary Movement CPPNPA: Experiences in a Hacienda in Negros Occidental, 1978-1995", in Patricio N. Abinales (ed.), The Revolution Falters: The Left in Philippine Politics After 1986 (Ithaca, NY, 1996), pp. IIO-I 53 . 
tuals, then, play an important role in the bridging and linking of networks and cultural frames.

A personal linkup between two or more popular intellectuals, each with their own audiences and social contacts, is one way in which such a brokerage and ideological "cross-fertilization" may take form. The cooperation between the Ecuadorian indigenous peasant leader, Gualavisí, and the urban, socialist leader, Paredes, in the I920s, is an example. "Gualavisí provided a bridge between two dramatically different worlds", writes Becker. As a peasant organizer and an active member of the Socialist Party, Gualavisí was able to connect a network of poor, Kichua-speaking, Indian peasants, with a network of urban, middle-class, Spanish-speaking, educated socialists. He also made this connection in ideological terms: he merged the socialist frame with local perceptions on class and ethnicity which, Becker argues, resonated with both Indian peasants and urban socialists. The fact that he was one of the few formally-educated and Spanish-speaking Indians in the area at the time, certainly added to his role. The cooperation between the two men who would develop into Sindhi nationalists, discussed by Verkaaik, forms another example. As politician and mystic, G.M. Syed connected to the Marxist teacher Ibrahim Joyo; he also connected to Joyo's network of activist Sindhi students, and the interactions led to an original form of Sindhi nationalism and to the beginnings of a separatist movement.

Once established, a social movement can function as a medium for such brokerage and mediation as well. It is then the task of movement intellectuals to connect their (prospective) constituency to new sources of ideas, and to new networks of movement activists and allies - a task that may eventually become institutionalized. As Eyerman notes for prewar Italy, the "vehicle" for the mediation "between the educated elite culture and the masses" was "the socialist movement and the public sphere it opened: newspapers, meeting houses, mass demonstrations and [...] factory councils". $4^{\circ}$ It needed to forge the necessarily channels of communication first. Antonio Gramsci, as a journalist and editor of a socialist newspaper, "embodied these mediating processes, it was he - and many others of course - who made it happen". ${ }^{4}$

The development of wider collective identities should be mentioned as an important effect of brokerage. "Brokerage creates new collective actors", as groups of people are connected into larger wholes, and may start to act as one. ${ }^{42}$ In the process, people adopt new, wider identities to which they attach collective rights and claims. Popular intellectuals are important in this process, as interpreters and promoters of specific

40. Eyerman, Between Culture and Politics, p. 8I.

4I. Ibid.

42. McAdam, Tarrow, and Tilly, Dynamics of Contention, p. I42. 
political identities. Thus, Colombian indigenous activists, in particular the "cultural activists", promoted the identity of an "indigenous people" as they forged connections between disparate Indian groups (Rappaport). Similarly, student-activists of a Sindhi nationalist movement who sought to recruit followers among worshippers at local Sufi shrines, tried to redefine their identity into a broader religious-nationalist one (Verkaaik).

It is interesting to note that academics may also function as cultural and social brokers. Anthropologists in Latin America linked academic interpretations to those of indigenous intellectuals and in the process helped to legitimize claims for indigenous rights. In Africa, locally trained anthropologists became important interpreters of African reality, and so partly reshaped the cultural and intellectual parameters of sociopolitical action. In so doing, they created a new interpretive frame through which local societies could come to grips with a rapidly changing social and political situation. Describing the position of these African assistants of Western anthropologists, who shaped so much of the anthropological knowledge of Africa, Lyn Schumaker writes:

Use of the term "intellectuals" [...] allows for different degrees and types of attachment to the local on the part of both assistants and anthropologists. "Intellectuals", in its broadest sense, refers to people who take an active and conscious role in shaping and elucidating various kinds of knowledge, whether or not their audiences recognize them as professionals. 43

\section{THE ROLE OF EDUCATION}

Since popular intellectuals are knowledge specialists, "education" in the broad sense of the term (learning and teaching new knowledge, new ideas) informs their activities and defines their position. In our definition of popular intellectuals, formal education, whether secular or religious, is not a necessary criterion. Popular intellectuals may emerge from their own local communities, their knowledge acquired outside of formal institutions of learning, often in the course of their activist careers. However, the essays in this Supplement demonstrate that many do derive their "cultural capital" from an advanced level of formal education ${ }^{44}$ - advanced, in comparison to the general level of education among their fellow activists and constituency, and in their society at large. This applies equally to "modern" education along Western lines, as to education in religious centres of learning, including Islamic schools and Catholic seminaries. Social movements, as we have seen, also try to create their own

43. Lyn Schumaker, Africanizing Anthropology: Fieldwork, Networks, and the Making of Cultural Knowledge in Central Africa (Durham, NC, 200I), p. I4-I s.

44. Alvin Gouldner developed the term "cultural capital" for the education-based knowledge of intellectuals; Alvin Gouldner, The Future of Intellectuals and the Rise of the New Class (New York, 1979), pp. I8-27. 
intellectuals, by means of alternative structures of schooling and training independent of elites and the state. This may well mark a phase in the development of a movement, when its ideology and activist frames have solidified into a standard repertoire. One example is the effort of the indigenous movement in Colombia (discussed by Rappaport) to set up its own schools to foster knowledge of indigenous culture and language, and develop cultural activists in the process.

This volume illustrates the salience of schooling in several ways. First, it draws attention to schools and universities as places of (creative) ideological work and as places where activist intellectual networks may be formed. Such processes may occur in the margins of these institutions, as the unintended consequences of educational policies. Where primary and secondary education are mainly intended to discipline and "civilize", 45 college and university may offer more "free spaces" for experimentation. Students may, furthermore, transform its intellectual contents into instruments of contentious action. The role of colonial high schools and universities in the development of nationalist, anticolonial intelligentsias is well-known. As Benedict Anderson has argued for southeast Asia, colonial teachings on the history of nationalism in Europe were applied by students to local situations and reworked into anticolonial nationalist ideologies. ${ }^{46}$ Moreover, universities provided new spaces for political discussions among students. This promoted student subcultures that drew on a variety of ideological sources. The social ties forged among likeminded classmates could develop into mobilizing networks for nascent social movements.

Of particular interest are the activist networks created by teachers. These teachers are educators with a mission: they try to create a new intelligentsia that actively engages in transforming or reforming society. For example, the two Sindhi nationalists discussed by Verkaaik were both, at least for part of their activist careers, teachers or educational reformers with the aim of creating a Sindhi intelligentsia. The schools they founded and the boarding houses they managed for their students (who came from villages in the region) became centres for activist networks among Sindhi students which would, in turn, form the core of a separatist movement. Activist teacher-student clusters also figure in Chabot's article. African-American theologists at Howard University familiarized their students with the ideology of Gandhian nonviolence, in the spirit of liberation theology, and formed a core of activist students who would play an important role in the civil rights movement. Similar patterns are found in very diverse movements. The revolutionary 
"Shining Path" in Peru traces its beginnings to the circle of students recruited by philosophy professor (and its leader) Abimael Guzmán, at the provincial university of Ayacucho. Islamic boarding schools in provincial towns of Asia may function as social and educational centres where intellectual leaders of Islamic movements recruit young followers.

A second point, which this volume illustrates, is the importance of education as a form of cultural capital for popular intellectuals. Formal education provides skills and knowledge for acting successfully in the public sphere, in particular in national and international arenas. Literacy, knowledge of the national language (and possibly international languages), the ability to address audiences, to negotiate with powerholders, and to speak to the media in a language that is understandable to a wider public, all require a certain expertise that is provided, in part, by formal education. The majority of popular intellectuals discussed in this volume would not have achieved their position as successful framing specialists, interlocutors, and social and cultural brokers, without a background in education. On the other hand, a convincing link to the experiential knowledge of the people they claim to represent, is essential as well. For example, the most visible popular intellectual in the antidam movement of the Narmada Valley in India, Mehda Patkar (discussed by Bose), was able to address the United States Congress and representatives of the World Bank in fluent English and with considerable technical expertise. At the same time, her prolonged visits to affected village communities, which started during her Ph.D. research in social work, provided her with the knowledge and experience that enabled her to communicate directly with villagers.

The potential friction between popular intellectuals with and without (formal) higher education is a third point of interest. The core of such frictions concerns the simple question: "Whose knowledge qualifies?". Among the Tuareg rebel leaders discussed by Lecocq, for example, the Western-educated intellectuals and the self-taught Tuareg migrant workers questioned the value of the other group's knowledge, and they criticized how this knowledge was put to use. This animosity surfaced in the condescending terms they used for one another. This became particularly clear when autodidact rebels lacked the required knowledge and skills to conduct negotiations with national governments, and depended on Western-educated Tuareg to do this in their place. Since social movements often include both types of intellectuals (with high and low levels of formal education), such tensions may be endemic. In conflicts about the "correct" interpretation of the (political) situation and the "right" choice of strategies and tactics, the battle lines may be drawn along this axis. Those with an advanced education can wield the argument that they have superior intellectual capabilities and access to better knowledge; 
those without may use the argument that they possess practical knowledge of what is going on "on the ground". ${ }^{47}$

The question whose knowledge prevails is also relevant with regard to gender differences. Though this issue has not been discussed explicitly in the contributions to this volume, we can venture a few remarks. A gender bias against women in education (both secular and religious) affects the opportunities for women to gain recognition as popular intellectuals, since education is, in many cases, an important basis for gaining respect as an "intellectual" - also in many social movements. To what extent social movements themselves discriminate against women in their schooling programmes, is a relevant point as well. When women perform as public spokespersons and inspirers of protest, they may be primarily perceived as persons rooted in the concerns of daily survival, and therefore as convincing interlocutors of public concerns..$^{8}$ A global rise in female enrolment in secondary schools and institutions of higher learning, and an increase in the number of women who take up the role of "public intellectual" in their societies (such as Arundhati Roy in India), certainly make a difference.

\section{INTELLECTUALS AND THE ISSUE OF REPRESENTATION}

The relationship between intellectual representation and political activities is one of the most politicized issues in social movements and contentious politics. Intellectual work is measured in terms of coherence and veracity; political activity is judged almost exclusively in terms of success. This tension makes the position of popular intellectuals highly complex, in particular when they have leadership roles within social movements. They have to worry constantly about the legitimacy and credibility of their position.

Wiktorowicz, in this issue, discusses the vilification and "decredentialing" of movement intellectuals as a strategy, used by opponents, to discredit these intellectuals in the eyes of fellow activists and wider publics. Such vilification may take place at all levels of contentious politics. The aim is to undermine the authority of a person to speak on behalf of a constituency or issue. In her analysis of indigenous pan-Maya activism in Guatemala, Diane Nelson observes: "Charges of being 'co-opted', 'manipulated', 'sold out', 'a demagogue', 'inauthentic' or not representing those you claim as followers are frequently lobbed at every target imaginable, including Maya rights activists, the guerrilla's, popular leaders, 
human rights groups, nongovernmental organizations, researchers, and the government". ${ }^{49}$ Such accusations can be observed in all political organizations, but it appears that leaders of informal, loosely organized social movements, who are not formally elected but emerge in the course of contention, are even more vulnerable to these kinds of attack.

The issue of representation and authority becomes even more highly charged in the case of popular intellectuals or leaders who do not originate in the groups they claim to represent. This issue of "outsiders" has been a crucial point of debate within and outside social movements. Bose shows how the two middle-class intellectuals, Roy and Patkar, were accepted for more or less tactical reasons by a large part of the anti-dam activists in Narmada. But he also makes clear that their position repeatedly came under fire because of the "prescriptive" notions concerning their role that prevailed within the movement: "there is a strong - if relatively undefined - set of assumptions regarding what the role of the popular intellectual should be". Popular intellectuals should, in this view, truly "support" a movement instead of playing a vanguardist role, and they should be truly committed and connected to the movement's constituency (Bose).

Similar processes have been observed in indigenous movements in Latin America which were supported, in an often uneasy alliance, by national and international activists and intellectuals. The support was gratefully accepted and could often be considered instrumental for the success of these movements. As happened in the case of the indigenous movement described by Rappaport, foreign anthropologists could even become custodians of the indigenous past. Nevertheless, the position of these sympathizers was always prone to criticism. It is clear that this issue has an additional interest for academic intellectuals who are engaged in these kinds of movements. They have to find a compromise between their political and academic work, but in this tension they always run the risk of generating criticism for "misrepresenting" the (indigenous) struggle, and distrust for not being committed enough to the struggle at hand. $5^{\circ}$ In her fascinating study on pan-Maya intellectuals in Guatemala, Kay Warren draws attention to the political importance of the question "who speaks for whom". ${ }^{\text {I }}$ She shows that this question affects the position both of insiders and outsiders: "It raises the issue of representation in both senses: who claims the authority to craft representations of ongoing social and political realities and who gains the position to represent others in public affairs?" 52

\footnotetext{
49. Diane M. Nelson, A Finger in the Wound: Body Politics in Quincentennial Guatemala (Berkeley, CA [etc.], I999), p. 34.

50. See, for instance, Les W. Field, "Complicities and Collaborations: Anthropologists and the 'Unacknowledged Tribes' of California”, Current Anthropology, 40 (1999), pp. 193-209.

5. Kay B. Warren, Indigenous Movements and Their Critics: Pan-Maya Activism in Guatemala (Princeton, NJ, 1998), pp. 19-20.

52. Ibid., p. 20.
} 
In addressing their various audiences, popular intellectuals need to establish credibility as spokespersons, inspirers, or intermediaries. As long as their appeal is focused on the individual wellbeing of their followers or members of their audience, their responsibility is limited; and so are the tensions in their public position. As soon as societal or political leverage becomes an issue, their position becomes more complicated. Popular intellectuals claim to engage in intellectual activity with the purpose of promoting the collective interests of popular classes, but there always remains the question whether they actually represent and articulate the latter's interests. They continually run the risk of losing contact with the rank-and-file. They may be judged by their audience as too "intellectual", in the sense that they give priority to analysis over militant praxis. They may also become too "contained" in the sense that their efforts to phrase claims in terms that are acceptable to the state and powerholders may frustrate the rank-and-file desire to confront authorities. Their position vis-à-vis powerholders, finally, may be ambiguous, and their possible insertion in (hegemonic) state projects may form an issue of intense debate - as it was in Gramsci's work.

The moment popular intellectuals connect to social movements, they become susceptible to the same kind of dynamics as the movement itself. As their position changes, so does the political impact and significance of their ideas and interpretations. Social movements emerge, articulate demands, find audiences, have their demands conceded or are repressed, get institutionalized or disappear. In the course of such historical cycles, the position of popular intellectuals - and their ideas - may be strengthened, marginalized, or outright contested. Such processes are highlighted, as we have seen throughout this volume, by a focus on the social and historical dynamics of intellectual activism. 